\title{
A Comparative Study of Growth Patterns in Crested Langurs and Vervet Monkeys
}

\author{
Debra R. Bolter \\ Department of Anthropology, Modesto College, 435 College Avenue, Modesto, CA 95350, USA \\ Correspondence should be addressed to Debra R. Bolter, bolterd@yosemite.edu
}

Received 14 October 2010; Accepted 21 December 2010

Academic Editor: Kathleen M. Muldoon

Copyright () 2011 Debra R. Bolter. This is an open access article distributed under the Creative Commons Attribution License, which permits unrestricted use, distribution, and reproduction in any medium, provided the original work is properly cited.

The physical growth patterns of crested langurs and vervet monkeys are investigated for several unilinear dimensions. Long bone lengths, trunk height, foot length, epiphyseal fusion of the long bones and the pelvis, and cranial capacity are compared through six dental growth stages in male Trachypithecus cristatus (crested langurs) and Cercopithecus aethiops (vervet monkeys). Results show that the body elements of crested langurs mature differently than those of vervets. In some dimensions, langurs and vervets grow comparably, in others vervets attain adult values in advance of crested langurs, and in one feature the langurs are accelerated. Several factors may explain this difference, including phylogeny, diet, ecology, and locomotion. This study proposes that locomotor requirements affect differences in somatic growth between the species.

\section{Introduction}

The fundamentals of growth and development are important in primate evolutionary studies. Primates have a protracted period of immaturity compared to other animals, and immature individuals must survive this prolonged life period before reproductive adulthood. When considering a life history perspective, natural selection acts on immature individuals first through survival, when mortality is quite high; only when an individual successfully navigates the long infant and juvenile stages does reproduction become a selective force. Emphasis on primate survival through immaturity and life history theory began in the 1980s and has become a major focus for primate researchers: we assess basic demographic variables like group composition and age at reproductive maturity, establish age-cohorts, follow changes in individuals as they mature, investigate patterns of sexual dimorphism, examine the influence of ecological and locomotor constraints, and explore maturity disassociations among body systems [1-16]. In order to determine the life history parameters for extinct species, paleontologists and paleoanthropologists must understand growth and development (e.g., [17-21]). Evolutionary theorists use displaced developmental events (from ancestor to descendant) to elucidate patterns of adaptations (heterochrony) or shifts in multidimensional, shape features (allometry) (e.g., $[22,23]$ ). A new term, sequence heterochrony, has been applied to investigations of the shift in developmental sequences from ancestor to descendants-a way to confer change (evolution) without novel traits (e.g., [24, 25]).

Long-term field studies on known individuals facilitate the correlation of an equivalent growth event: for example, juvenile independence with dental development and social maturation with reproductive anatomy (e.g., $[2,26])$. Much of the long-term fieldwork in Old World monkeys comes from the cheek-pouched cercopithecines (e.g., [11, 27-30]); somewhat less information is available for the colobines (e.g., [31]). Skeletal materials in museums provide additional information on the life history events in Old World monkeys, for example, in the correlation between the emergence of M1 and $90 \%-95 \%$ of brain growth [32].

Although wild, naturally ranging primates are the preferred focus for developmental studies, nevertheless, life history stages for captive animals may be conducted using techniques not easily derived from wild populations. Colony animals permit longitudinal monitoring, which provides species data on dental development, skeletal maturity, body masses, and reproductive physiology (e.g., [33-40]). 
TABLE 1: Life history features for Trachypithecus cristatus and Cercopithecus aethiops.

\begin{tabular}{cccccccccc}
\hline $\begin{array}{c}\text { Gestation } \\
\text { (days) }\end{array}$ & $\begin{array}{c}\text { First } \\
\text { birth } \\
\text { (years) }\end{array}$ & $\begin{array}{c}\text { Interbirth } \\
\text { interval } \\
\text { (months) }\end{array}$ & $\begin{array}{c}\text { Birth } \\
\text { season? }\end{array}$ & $\begin{array}{c}\text { Life } \\
\text { span } \\
\text { (years) }\end{array}$ & $\begin{array}{c}\text { Female } \\
\text { adult body } \\
\text { mass (kg) }\end{array}$ & $\begin{array}{c}\text { Male adult } \\
\text { body mass } \\
\text { (kg) }\end{array}$ & $\begin{array}{c}\text { Male adult } \\
\text { brain size } \\
\text { (cc) }\end{array}$ & Diet & Locomotion \\
\hline T. cristatus & $\sim 180$ & $\sim 4$ & $16.5-24$ & No & UNK & 5.8 & 6.6 & 67 & $\begin{array}{c}\text { Mature \& young } \\
\text { leaves, fruits, } \\
\text { flowers } \\
\text { Arboreal } \\
\text { quadruped } \\
\text { C. aethiops }\end{array}$ \\
162 & $3-5$ & 20.4 & Yes & 31 & 3.5 & 5.8 & 69 & $\begin{array}{c}\text { Vertebrates, eggs, } \\
\text { snails, corms, } \\
\text { bulbs, fruits }\end{array}$ \\
\hline
\end{tabular}

Data from $[11,12,35,46-61]$.

However, as the circumstances of growth differ between wild and captive individuals, the timing of development differs in the two settings (e.g., [10,41-45]).

This study provides a first step to consider body maturity in wild-collected, local populations of two Cercopithecidae: Asian crested langurs (Trachypithecus cristatus) and African vervet monkeys (Cercopithecus aethiops). Table 1 compares the life history variables and their species traits. In both species, the length of gestation is the same, between 5.5 to 6 months; the first birth occurs around 4 years whereas males become reproductively mature at about 5 years. Physical markers of life history are comparable, with first molar (M1) emergence at 1 year of age and third molar (M3) emergence as early as 3 years in both species, with no notable sex differences in timing. Male crested langurs average $6.6 \mathrm{~kg}$, and male vervets $5.8 \mathrm{~kg}$.

This study investigates and compares the development of long bone length, brain size, skeletal fusion, and body mass between langurs and vervets. To control for the time dimension, molar eruptions are used to standardize the comparisons. Males are the focus because female vervets are lighter than female langurs.

I test the hypothesis that body systems (brain, skeleton, and linear dimensions) in male crested langurs grow the same as that of male vervets. By holding dental growth constant, the evaluation of the other systems is possible. Dental development thus becomes the chronological marker for comparison and contrast of crested langurs and vervets at critical stages of life-almost anatomical "snap-shots."

\section{Methods}

Thirty-three male Trachypithecus cristatus (17 immature, 16 adult) were wild shot in the 1937 Asiatic Primate Expedition (A.P.E.) in North Boreno under the direction of Adolph Schultz and assisted by Sherwood Washburn (cf [62]). Ten years later Washburn collected 35 male Cercopithecus aethiops (13 immature, 22 adult) in Uganda over a 35-day period. Individuals for each population span all immature age classes, although the sample sizes are small.

For both species, each animal was weighed at once, linear measurements were taken, and external features noted (see Table 2). Field notes recorded the sex (visual assessment), measurements on trunk height (symphysion to suprasternal
TABLE 2: Available data for the two collections.

\begin{tabular}{ll}
\hline Field data & Lab data \\
\hline Sex & Cranial capacity \\
Trunk height & Dental emergence \\
Tail length & Humerus length \\
Foot length & Radius length \\
Body mass & Femur length \\
& Tibia length \\
& Epiphyseal fusion \\
& Pelvic fusion \\
\hline
\end{tabular}

notch), length of tail and foot, and body mass (anthropometrics after [63]).

In the laboratory dental eruption, epiphyseal and pelvic fusion were assessed. Maximum lengths of the limb bones were measured after Schultz [63]. Cranial capacity, an indirect indicator of brain size, was measured with mustard seed and the volume recorded to the nearest milliliter (see Table 2).

2.1. Animal Sample: Dental Age Classes for Basis of Life Stages. Age classes in the two species are defined by molar emergence. Those individuals without permanent dentition were classified as "infant," those with fully erupted molars and fused proximal humeri as "adult", and the intermediaries as "juvenile" (see Table 3).

Analysis of dentition is the standard method by which to organize age classes across species (e.g., [67]). In colobines, the posterior molar teeth or "new" teeth erupt before their anterior incisor and canine ones, or "replacement" teeth (e.g., $[46,68,69])$. This pattern contrasts with noncolobines, in which the posterior teeth emerge later in the sequence $[68,70]$. Individuals in this study are classified based on permanent molars emergence. For all primates M1 erupts after deciduous dentition has erupted, followed by the M2 and M3. These categories are limited to molar eruptions and therefore allow refinement of juvenile life stages, thus eliminating the problem introduced by variations in anterior/posterior eruption schedules across larger taxonomic divides. 
TABLE 3: Age classes for crested langurs and vervets.

\begin{tabular}{|c|c|c|c|c|c|c|}
\hline \multicolumn{2}{|c|}{ Langurs } & \multicolumn{3}{|c|}{ Age classes } & \multicolumn{2}{|c|}{ Vervets } \\
\hline $\begin{array}{l}\text { Crested langur } \\
\text { sample size }\end{array}$ & Age in years ${ }^{1}$ & Age class & Life stage & Tooth emergence (Maxilla) & Age in years ${ }^{2}$ & Vervet sample size \\
\hline $2-\sigma^{\pi}$ & $0-.4$ & 1 & Infant & Partial deciduous & $0-.3$ & $2-0^{x}$ \\
\hline $2-0^{x}$ & $.4-1$ & 2 & & Deciduous & $.3-1$ & $2-0^{x}$ \\
\hline $7-0^{7}$ & $1-2$ & 3 & & M1 & $1-2.2$ & $2-o^{7}$ \\
\hline $3-0^{7}$ & $2-3$ & 4 & Juvenile & M2 & $2.2-3.2$ & $4-0^{7}$ \\
\hline $3-0^{7}$ & $3-5^{3}$ & 5 & & M3 & $3.2-4.5$ & $3-0^{7}$ \\
\hline $16-0^{7}$ & $>5$ & 6 & Adult & Full (proximal humerus fused) & $>4.5$ & $22-\sigma^{7}$ \\
\hline
\end{tabular}

${ }^{1}$ Based on [49] for crested langurs. Ages are based on gingival emergence times of captured wild crested langurs examined at 3-month intervals, except where noted.

${ }^{2}$ Based on Fairbanks, pers. comm. Ages are from known-age captive individuals in a vervet colony housed at UCLA-VA Vervet Research Center.

${ }^{3}$ Based on crested langurs reaching adult physical strength at about 6 years [49], Francois' langur males reaching reproductive maturity at 5 years [64] as cited in [65] and Phayre's males reaching adulthood at 5 years [66].

Dental emergence chronologies from live animals have been documented for both species to serve as supplemental data for this analysis. Gingival emergence is slightly later than the emergence through the alveolar bone and therefore the chronologies in Table 3 may overestimate the age of the skeletal age classes up to 3 months [71].

Wolf [49] documents gingival emergence times of wild crested langurs that correspond with the predicted timing sequences published by Smith et al. [70], Godfrey et al. [12], and Dirks [13] for African and Asian colobine species. These times are found in Table 3. For the vervets, gingival emergence times come from two vervet colonies on individuals of known age $[33,40]$. The vervet age classes are revised from a previously published paper to allow comparison with the langurs [60]. Note that since dental growth is faster in captive versus wild primates, wild vervets' ages may be underestimated by as much as 9 months (based on M3 eruption in captive baboons 18 months earlier than in their wild counterparts [41], and baboons requiring twice the time to mature as vervets).

Eruptions of maxillary teeth for this study were visually assessed and assigned scores based on Wintheiser et al. [72] $(1=$ unerupted, $2=$ partial eruption, $3=$ full eruption $)$. The upper dentition was chosen because these teeth were most often preserved as part of the cranium, and therefore maximized the specimens for study.

Skeletal fusion stages of the long bones and pelvis were assigned according to Wintheiser et al. [72] methods ( $1=$ no union-two pieces of bone with no connection, 2 = partial union-bony connection between bone elements, with an opening between them, 3 = full union-complete fusion, no opening). Study skeletons were fully macerated so that the bones were free of cartilaginous tissue, except in the cases of newborns. The ossification event, once initiated, occurs quickly [73] which makes classification into the three categories unambiguous. Postcranial markers are added to the age class categories in order to separate immature from adult since the dentition completes growth before the postcrania (e.g., $[46,74]$ ). The proximal humerus is the last long bone to fuse in monkeys [75], and this skeletal element divided immature from adult and serves as a marker for use across taxa (e.g., $[44,60])$.

2.2. Data Analysis to Compare Sequence and Timing of Growth. Each individual was (1) scored for dental emergence and skeletal fusion, (2) assigned a dental age class, and (3) measured for cranial capacity, skeletal fusion, and limb bone lengths. In evaluating the fusions of skeletal elements, the most advanced fusion state was taken per age class.

2.2.1. Analyzing Order of Body Growth. To configure the percentage dental emergence completed in juveniles, eruption scores were added together and divided by the scores for adults (after [60]). To configure overall skeletal maturity in juveniles, the following 19 epiphyseal union scores were added together and divided by the scores for adults: proximal $(p)$, medial, and distal $(d)$ humerus; $p$ and $d$ radius, ulna, tibia, fibula, femur; greater and less trochanter of femur; three borders of the acetabulum and the ischiopubic ramus.

2.3. Statistical Analysis. Descriptive statistics were taken for juvenile and adult age classes. Analysis of variance (ANOVA) was calculated for linear and mass measurements across age classes 3,4 , and 5 to be compared with the adult stage, age class $6 . P \leq .05$ was taken as significant.

\section{Results}

3.1. Skeletal Growth Patterns: Epiphyseal Fusions. Fusion that begins at the ischiopubic ramus in the infant is completed by class 2 (see Table 4). Fusion within the acetabulum begins in vervets during class 3 , in langurs class 4 and is completed during class 5 in both species.

In both species, fusion of the long bones begins at the elbow joint in class 3 but the sequence of fusion varies between species. In langurs, most skeletal elements fuse after M3 emergence, class 5, whereas vervet males have a more mosaic skeletal maturity from class 3-5 (see Table 5). 
TABle 4: Age class at which skeletal fusions occurs-Males Only. Shading indicates difference between species.

\begin{tabular}{lcc}
\hline & Langurs & Vervets \\
\hline Pelvis & Age class at which fusion initiates \\
Ischiopubic ramus & 2 & 2 \\
Acetabulum & 4 & 3 \\
Long bones & & \\
Elbow & 3 & 3 \\
Hip & 5 & 4 \\
Ankle & 5 & 3 \\
Knee & 5 & 6 \\
Wrist & 5 & 5 \\
Shoulder & 5 & 5 \\
\hline
\end{tabular}

TABLE 5: Age class at which male adult linear and mass dimensions achieved $(P<.05)$. Shading indicates difference between species.

\begin{tabular}{lcc}
\hline Dimensions & Langurs & \multicolumn{2}{c}{ Vervets } \\
& \multicolumn{2}{c}{ Adult dimensions } \\
\hline Cranial capacity & 3 & 3 \\
Humerus & 6 & 5 \\
Radius & 6 & 5 \\
Femur & 5 & 5 \\
Tibia & 6 & 5 \\
Tail & 5 & 5 \\
Foot & 6 & 5 \\
Trunk height & 6 & 6 \\
Body mass & 6 & 6 \\
\hline
\end{tabular}

3.2. Skeletal Growth Patterns: Linear Dimensions. Crested langurs in class 5 compared to adults (age class 6) have statistically significantly shorter linear dimensions for all measurements except for the tail and femur. In terms of ranges, two "small" adults consistently fall within the age class 5 individual ranges $(n=3)$ for the humerus, radius, tibia, and trunk length, while the majority of adults fall outside of the range $(n=14)$.

In vervets, all long bones, the tail and the foot in age class 5 animals are not statistically different from adult lengths, whereas the trunk height in age class 5 is significantly shorter (see Table 6, Figures 1 and 2). When considering the range of adult values, one lone age class 6 male has a trunk length of $310 \mathrm{~mm}$ while the age class 5 males measure 320,320, and 326; all other adult males $(n=19)$ have trunks that range from $330-376 \mathrm{~mm}$.

3.3. Body Growth Patterns: Mass Dimensions. In both species, cranial capacity reaches over $90 \%$ completion by 1 st molar eruption (class 2) and body mass in late juveniles (class 5) falls significantly below the range of adults (see Figure 3 ). In langurs, age class 5 males range $5.0-5.9 \mathrm{~kg}$, while age class 6

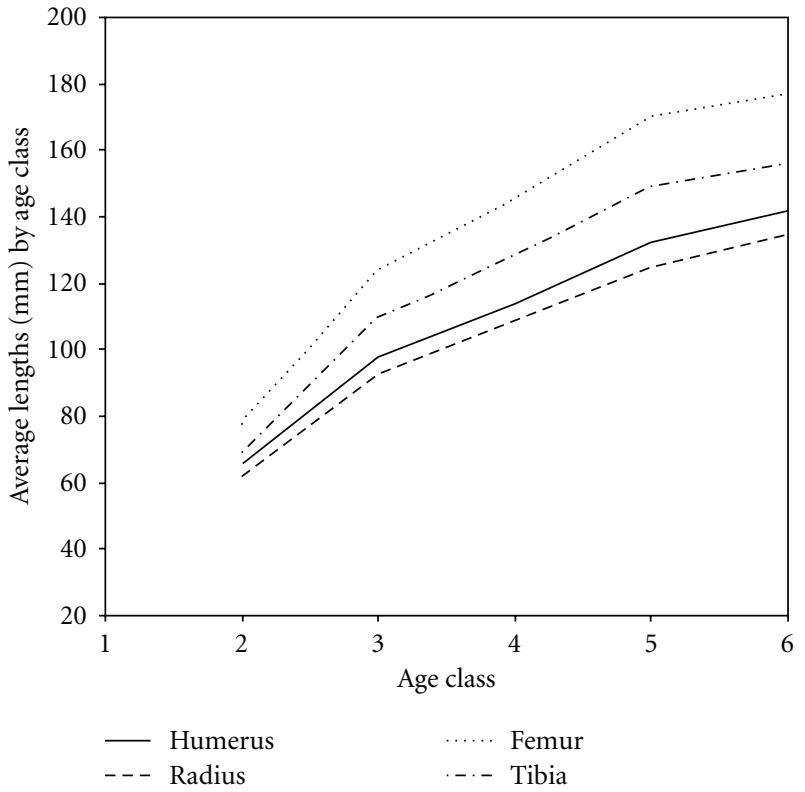

(a)

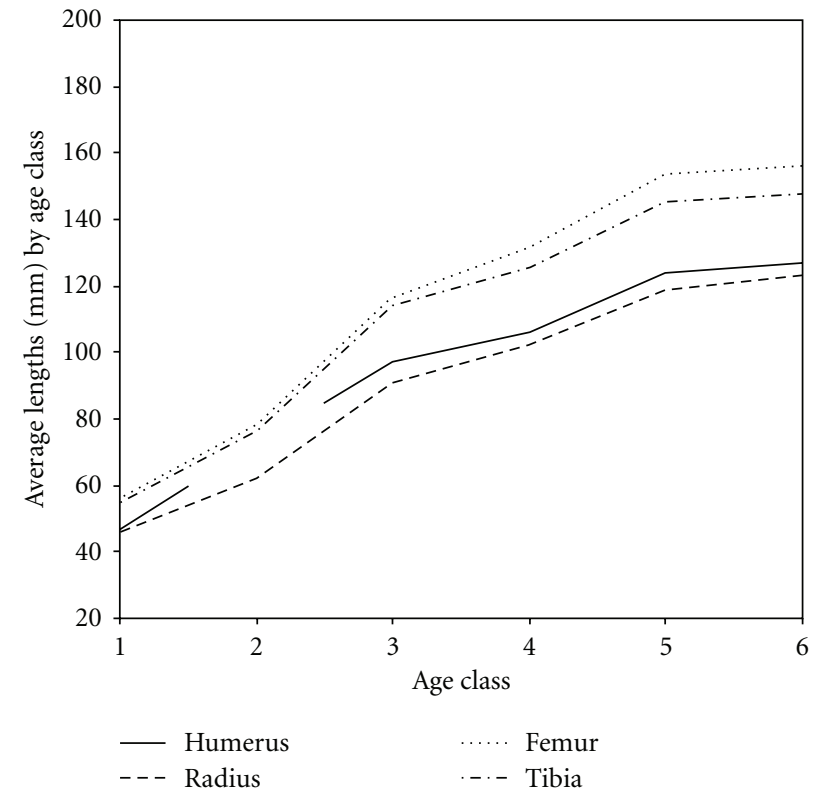

(b)

FIGURE 1: Average maximum long bone length $(\mathrm{mm})$ in relation to age class for (a) langurs and (b) vervets.

adults range $5.7-7.9 \mathrm{~kg}$. In vervets, age class 5 males range $3.9-5.4 \mathrm{~kg}$, while adults range between $4.1-7.3 \mathrm{~kg}$.

3.4. Order of Growth in Body Systems. Crested langurs and vervets show the same order of the maturation in body dimensions, proportions, dentition, and skeleton (see Table 7).

3.5. Timing of Growth in Body Systems. Table 8 shows the percent adult value for linear and mass dimensions by species. Langur and vervet newborns are proportional in 
TABle 6: Means, sample size, and standard deviations for linear and mass dimensions by juvenile and adult age classes—-Males Only. All measurements in millimeters, except body mass in kilograms.

(a)

\begin{tabular}{|c|c|c|c|c|c|c|c|c|}
\hline & \multicolumn{2}{|c|}{ Humerus } & \multicolumn{2}{|c|}{ Radius } & \multicolumn{2}{|c|}{ Femur } & \multicolumn{2}{|c|}{ Tibia } \\
\hline & Langur & Vervet & Langur & Vervet & Langur & Vervet & Langur & Vervet \\
\hline Age class 3 & $\begin{array}{c}98.0 \\
n=7 \\
\mathrm{SD}=10.6\end{array}$ & $\begin{array}{c}97.5 \\
n=2\end{array}$ & $\begin{array}{c}92.3 \\
n=7 \\
\mathrm{SD}=9.4\end{array}$ & $\begin{array}{c}90.5 \\
n=2\end{array}$ & $\begin{array}{c}124.2 \\
n=7 \\
\mathrm{SD}=13.6\end{array}$ & $\begin{array}{l}116.5 \\
n=2\end{array}$ & $\begin{array}{c}109.7 \\
n=7 \\
\mathrm{SD}=11.8\end{array}$ & $\begin{array}{l}114.0 \\
n=2\end{array}$ \\
\hline Age class 4 & $\begin{array}{c}114.0 \\
n=3 \\
\mathrm{SD}=8.1\end{array}$ & $\begin{array}{l}106.0 \\
n=4\end{array}$ & $\begin{array}{c}109.1 \\
n=3 \\
\mathrm{SD}=7.7\end{array}$ & $\begin{array}{l}102.8 \\
n=4\end{array}$ & $\begin{array}{c}145.5 \\
n=3 \\
\mathrm{SD}=10.2\end{array}$ & $\begin{array}{l}131.8 \\
n=4\end{array}$ & $\begin{array}{c}128.2 \\
n=3 \\
\mathrm{SD}=8.2\end{array}$ & $\begin{array}{l}126.0 \\
n=4\end{array}$ \\
\hline Age class 5 & $\begin{array}{c}132.3 \\
n=2 \\
\mathrm{SD}=.8\end{array}$ & $\begin{array}{c}123.7 \\
n=3 \\
\mathrm{SD}=3.1\end{array}$ & $\begin{array}{c}124.8 \\
n=2 \\
\mathrm{SD}=.7\end{array}$ & $\begin{array}{c}118.7 \\
n=3 \\
\mathrm{SD}=4.5\end{array}$ & $\begin{array}{c}170.1 \\
n=2 \\
\mathrm{SD}=5.5\end{array}$ & $\begin{array}{c}153.7 \\
n=3 \\
\mathrm{SD}=6.8\end{array}$ & $\begin{array}{c}149.0 \\
n=3 \\
\mathrm{SD}=.6\end{array}$ & $\begin{array}{c}145.3 \\
n=3 \\
\mathrm{SD}=7.2\end{array}$ \\
\hline Age class 6 & $\begin{array}{c}141.7 \\
n=16 \\
\mathrm{SD}=5.8\end{array}$ & $\begin{array}{c}127.2 \\
n=17 \\
\mathrm{SD}=4.2\end{array}$ & $\begin{array}{c}134.3 \\
n=16 \\
\mathrm{SD}=4.6\end{array}$ & $\begin{array}{c}123.1 \\
n=17 \\
\mathrm{SD}=3.4\end{array}$ & $\begin{array}{c}177.0 \\
n=16 \\
\mathrm{SD}=7.6\end{array}$ & $\begin{array}{c}156.1 \\
n=17 \\
\mathrm{SD}=4.6\end{array}$ & $\begin{array}{c}156.0 \\
n=16 \\
\mathrm{SD}=5.1\end{array}$ & $\begin{array}{c}147.5 \\
n=18 \\
\mathrm{SD}=4.6\end{array}$ \\
\hline
\end{tabular}

(b)

\begin{tabular}{|c|c|c|c|c|c|c|c|c|}
\hline & \multicolumn{2}{|c|}{ Foot } & \multicolumn{2}{|c|}{ Tail } & \multicolumn{2}{|c|}{ Trunk } & \multicolumn{2}{|c|}{ Body Mass } \\
\hline & Langur & Vervet & Langur & Vervet & Langur & Vervet & Langur & Vervet \\
\hline Age class 3 & $\begin{array}{c}122.5 \\
n=4 \\
\mathrm{SD}=12.3\end{array}$ & $\begin{array}{l}115.5 \\
n=2\end{array}$ & $\begin{array}{c}491.3 \\
n=4 \\
\mathrm{SD}=54.8\end{array}$ & $\begin{array}{l}435.0 \\
n=2\end{array}$ & $\begin{array}{c}235.8 \\
n=4 \\
\mathrm{SD}=27.5\end{array}$ & 249.0 & $\begin{array}{c}2.0 \\
n=4 \\
\mathrm{SD}=.6\end{array}$ & 2.0 \\
\hline Age class 4 & $\begin{array}{c}136.5 \\
n=2 \\
\mathrm{SD}=5.0\end{array}$ & $\begin{array}{l}125.0 \\
n=4\end{array}$ & $\begin{array}{c}562.5 \\
n=2 \\
\mathrm{SD}=3.5\end{array}$ & $\begin{array}{l}576.7 \\
n=3\end{array}$ & $\begin{array}{c}273.5 \\
n=2 \\
\mathrm{SD}=9.2\end{array}$ & 278.8 & $\begin{array}{c}2.8 \\
n=2 \\
\mathrm{SD}=.2\end{array}$ & 3.2 \\
\hline Age class 5 & $\begin{array}{c}154.7 \\
n=3 \\
\mathrm{SD}=5.5\end{array}$ & $\begin{array}{l}138.0 \\
n=3\end{array}$ & $\begin{array}{c}681.7 \\
n=3 \\
\mathrm{SD}=15.3\end{array}$ & $\begin{array}{l}610.0 \\
n=3\end{array}$ & $\begin{array}{c}337.7 \\
n=3 \\
\mathrm{SD}=15.0\end{array}$ & $\begin{array}{c}322.0 \\
n=3 \\
\mathrm{SD}=3.5\end{array}$ & $\begin{array}{c}5.4 \\
n=3 \\
\mathrm{SD}=.5\end{array}$ & $\begin{array}{c}4.6 \\
n=3 \\
\mathrm{SD}=.8\end{array}$ \\
\hline Age class 6 & $\begin{array}{c}161.7 \\
n=12 \\
\mathrm{SD}=4.8\end{array}$ & $\begin{array}{c}139.9 \\
n=18\end{array}$ & $\begin{array}{c}707.9 \\
n=12 \\
\mathrm{SD}=30.9\end{array}$ & $\begin{array}{c}617.0 \\
n=15\end{array}$ & $\begin{array}{c}366.1 \\
n=12 \\
\mathrm{SD}=11.0\end{array}$ & $\begin{array}{c}346.7 \\
n=20 \\
\mathrm{SD}=15\end{array}$ & $\begin{array}{c}6.6 \\
n=12 \\
\mathrm{SD}=.7\end{array}$ & $\begin{array}{c}5.8 \\
n=21 \\
\mathrm{SD}=.7\end{array}$ \\
\hline
\end{tabular}

size compared to respective adult values. In age class $2-5$, langurs are smaller (compared to adults) than vervets. The one exception is age class 5 body mass.

\section{Discussion}

This study offers a focused comparison between two Old World monkeys to establish growth patterns in several unilinear body dimensions. Further detailed studies on primate growth are required to ascertain which sequence reflects the ancestral condition of the Cercopithecoidea, and therefore this study precludes a heterochronic analysis (cf. [23]). Likewise, as multidimensional shape changes are not being investigated, allometric scaling cannot be applied to these data.

4.1. Similarities between Crested Langurs and Vervets. The order of maturity of body systems between crested langurs and vervets is consistent (refer to Table 7). The brain matures first, then the linear dimensions of the tail, limbs, and finally the trunk. Body mass and epiphyseal closure are the last features to change. This sequence of growth supports the hypothesis of Bolter and Zihlman [60] that the order represents a conservative pattern in catarrhines. Their order of skeletal fusion in the long bones is also similar. The distal humerus is the first to fuse, the proximal humerus one of the last. The forelimb fusion is also consistent between vervets and langurs: elbow elements unite in class 3, with wrist and shoulder elements fusing during class 5 . A significant proportion of growth occurs during the late juvenile stage in both species-that is, after all permanent teeth have emerged. For example, males reach adult lengths in the tail and femur during class 5 (langurs: $3-5$ years; vervets: 3.2-4.5 years). Adult trunk height is achieved in langurs and vervets in class 6 .

4.2. Differences between Crested Langur and Vervet Maturity. Vervets initiate fusion in several bone elements before langurs: at the ankle and hip joint and reach adult lengths before langurs in the tail, long bones, and foot.

Fusion of the elements of the hindlimb and hip is accelerated in vervets relative to langurs. Fusion of the ankle 


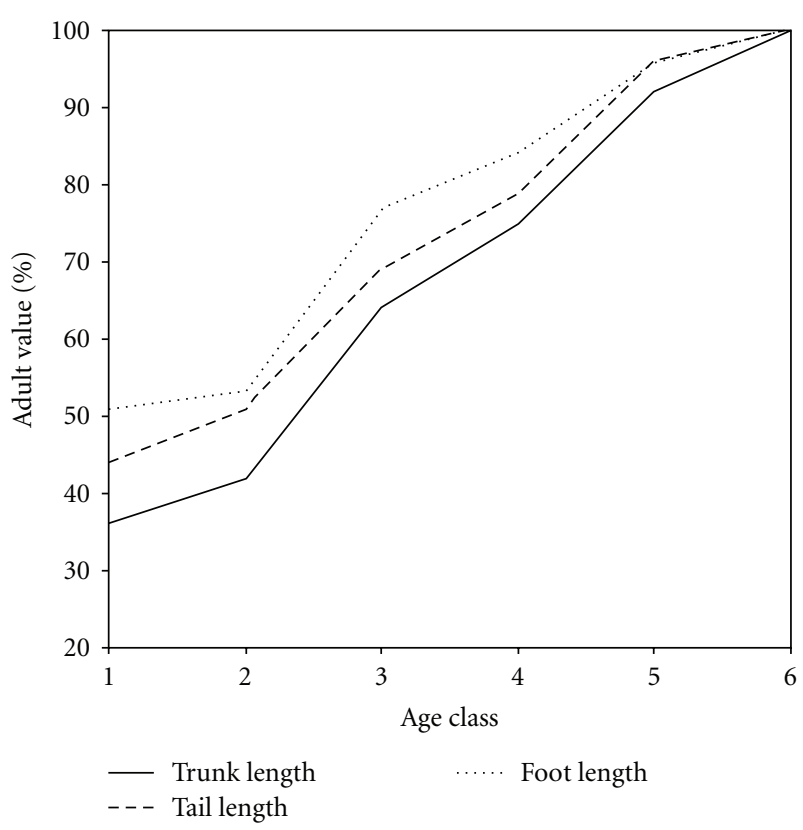

(a)

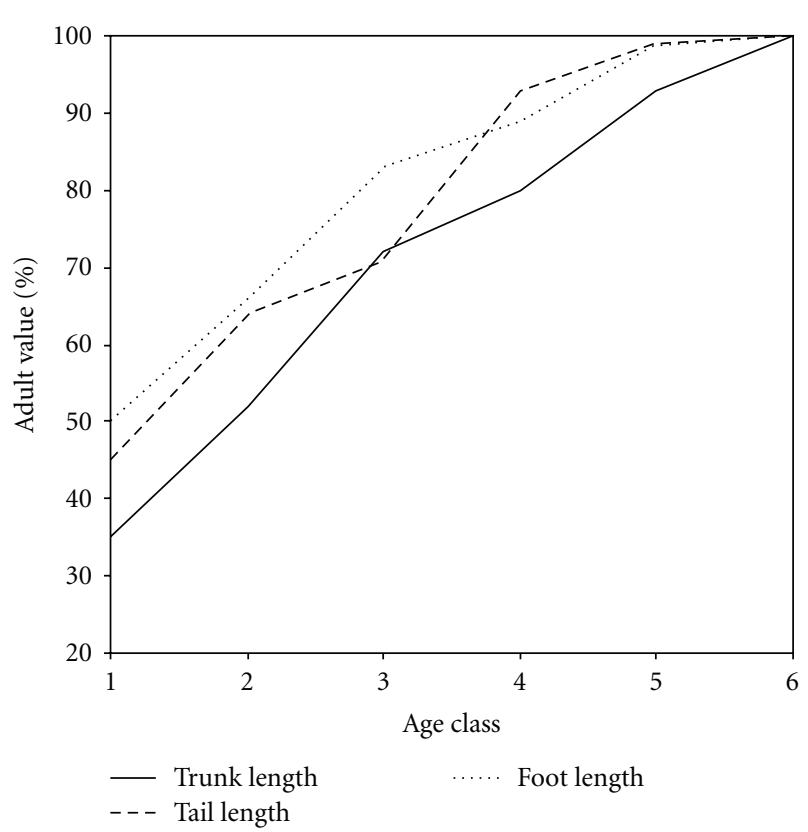

(b)

FIGURE 2: Relative lengths in mm (against adult values) in relation to age class for (a) langurs and (b) vervets.

joint occurs over class 2-3 in the vervets, in class 5 in langurs. Hip joint fusion at the acetabulum and proximal femur begins in the vervets about 1 year before langurs. In one element of the hindlimb, the knee joint, the distal femur and proximal tibia of the langurs are accelerated compared with vervets.

The tail matures faster in vervets than in langurs. The tail of the langur $2-3$ years old is only $79 \%$ of adult values ( $562.5 \mathrm{~mm}$ versus $707.9 \mathrm{~mm}$ ). The 2.2-3.2-year-old vervets

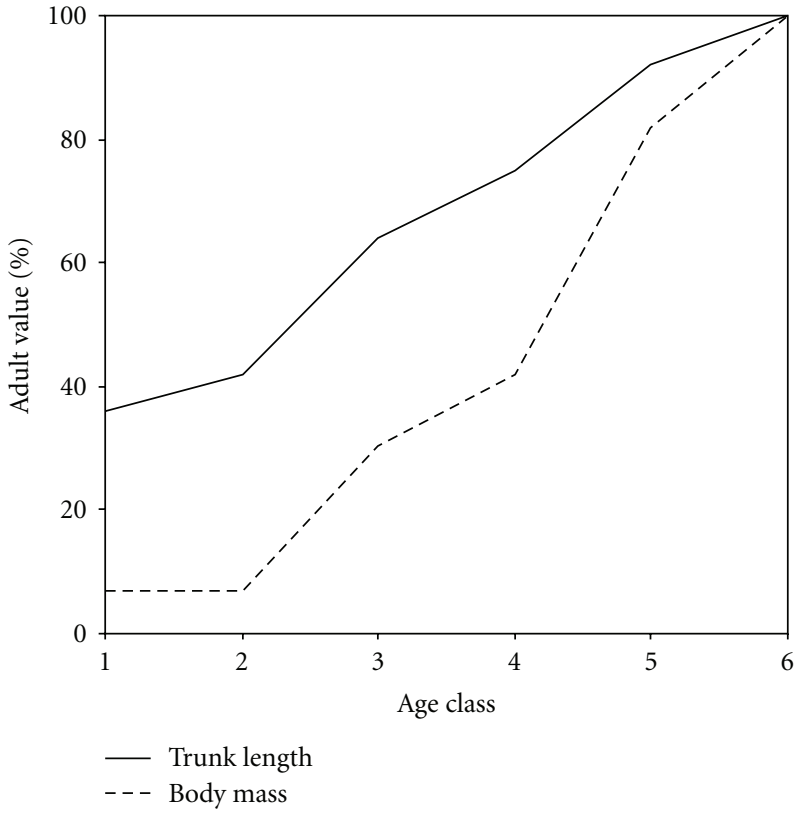

(a)

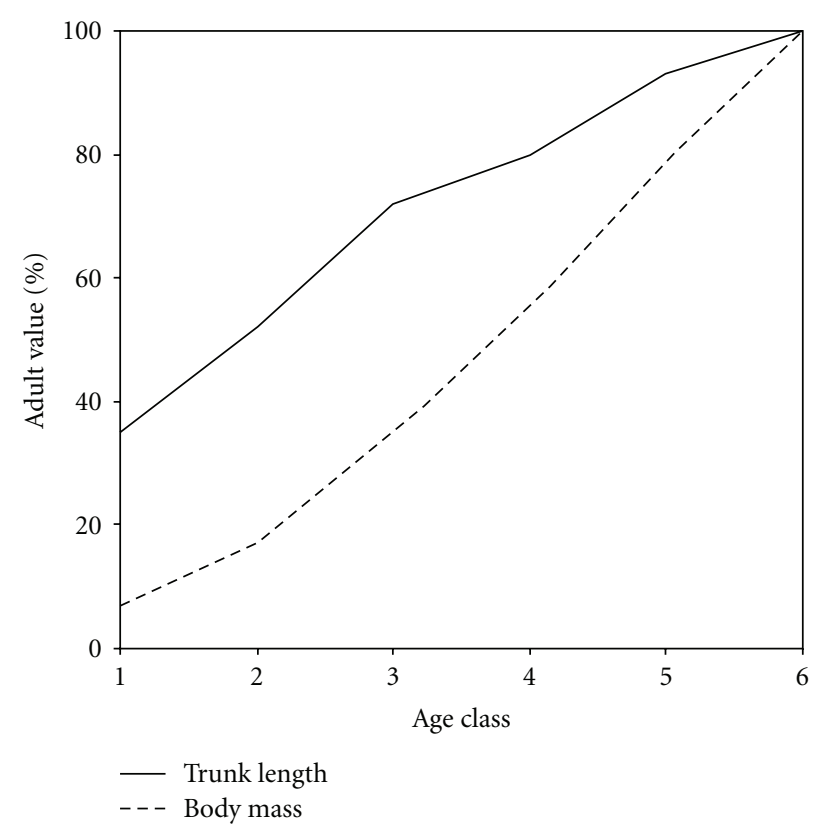

(b)

FIgure 3: Percent body mass and trunk height attained by age class for (a) langurs and (b) vervets.

are over $90 \%$ of adult size $(576.7 \mathrm{~mm}$ versus $617.0 \mathrm{~mm})$. However, adult lengths are not reached until class 5 in both species.

Long bone and foot lengths reach adult proportions in class 5 in vervets, whereas in langurs of similar age the humerii, radii, tibiae, and hindfeet are statistically shorter. In the crested langur, some long bones (humerus, radius, tibia) fuse before adult lengths are achieved. One explanation is that the bones are remodeled as muscularity increases. 
TABLE 7: Traits of male juveniles as a percentage of adult means to highlight the order of body systems maturity ${ }^{4}$.

\begin{tabular}{|c|c|c|c|c|c|c|}
\hline \multirow[b]{2}{*}{ Body system } & \multicolumn{3}{|c|}{ Crested langurs (9) } & \multicolumn{3}{|c|}{ Vervet monkeys (9) } \\
\hline & Juvenile Mean & Adult Mean & $\%$ Growth Completed & $\%$ Growth Completed & Adult Mean & Juvenile Mean \\
\hline Cranial cap. (cc) & 64 & 67 & $96 \%$ & $99 \%$ & 69 & $68^{5}$ \\
\hline Foot $(\mathrm{mm})$ & 136.3 & 161.7 & $84 \%$ & $91 \%$ & 139.9 & 127.2 \\
\hline Tail & 570.6 & 707.9 & $81 \%$ & $92 \%$ & 617 & $570.7^{6}$ \\
\hline Femur (mm) & 137.1 & 177.0 & $77 \%$ & $87 \%$ & 156.1 & 135.7 \\
\hline Humerus (mm) & 107.7 & 141.7 & $76 \%$ & $87 \%$ & 127.2 & 110 \\
\hline Trunk (mm) & 278.1 & 366.1 & $76 \%$ & $83 \%$ & 346.7 & 286.6 \\
\hline Body mass (kg) & 3.3 & 6.6 & $50 \%$ & $59 \%$ & 5.8 & 3.4 \\
\hline Skeleton & 27 & 57 & $47 \%$ & $47 \%$ & 57 & 27 \\
\hline
\end{tabular}

${ }^{4}$ Only those individuals with data for all 19 epiphyseal scores, dental scores, long bone lengths and trunk height, and body masses were included, unless otherwise noted.

${ }^{5} n=8$ missing data point for one age class 5 individual

${ }^{6} n=7$; missing data point for one age class 3 and one age class 4 individual.

TABLe 8: Percent adult size achieved and sample size for each age class-Males Only.

(a) (Each immature age class mean divided by age class 6 (adult) mean)

\begin{tabular}{|c|c|c|c|c|c|c|c|c|}
\hline & \multicolumn{2}{|c|}{ Humerus } & \multicolumn{2}{|c|}{ Femur } & \multicolumn{2}{|c|}{ Trunk } & \multicolumn{2}{|c|}{ Body mass } \\
\hline & Langur & Vervet & Langur & Vervet & Langur & Vervet & Langur & Vervet \\
\hline Age class 1 & nd & $\begin{array}{c}37 \\
n=1\end{array}$ & nd & $\begin{array}{c}36 \\
n=1\end{array}$ & $\begin{array}{c}36 \\
n=2\end{array}$ & $\begin{array}{c}35 \\
n=2\end{array}$ & $\begin{array}{c}7 \\
n=2\end{array}$ & $\begin{array}{c}7 \\
n=2\end{array}$ \\
\hline Age class 2 & $\begin{array}{c}46 \\
n=2\end{array}$ & nd & $\begin{array}{c}44 \\
n=2\end{array}$ & $\begin{array}{c}50 \\
n=2\end{array}$ & $\begin{array}{c}42 \\
n=1\end{array}$ & $\begin{array}{c}52 \\
n=2\end{array}$ & $\begin{array}{c}7 \\
n=1\end{array}$ & $\begin{array}{c}17 \\
n=2\end{array}$ \\
\hline Age class 3 & $\begin{array}{c}69 \\
n=7\end{array}$ & $\begin{array}{c}77 \\
n=2\end{array}$ & $\begin{array}{c}70 \\
n=7\end{array}$ & $\begin{array}{c}75 \\
n=2\end{array}$ & $\begin{array}{c}64 \\
n=4\end{array}$ & $\begin{array}{c}72 \\
n=2\end{array}$ & $\begin{array}{c}30 \\
n=4\end{array}$ & $\begin{array}{c}35 \\
n=2\end{array}$ \\
\hline Age class 4 & $\begin{array}{c}80 \\
n=3\end{array}$ & $\begin{array}{c}83 \\
n=4\end{array}$ & $\begin{array}{c}82 \\
n=3\end{array}$ & $\begin{array}{c}84 \\
n=4\end{array}$ & $\begin{array}{c}75 \\
n=2\end{array}$ & $\begin{array}{c}80 \\
n=3\end{array}$ & $\begin{array}{c}42 \\
n=2\end{array}$ & $\begin{array}{c}55 \\
n=3\end{array}$ \\
\hline Age class 5 & $\begin{array}{c}93 \\
n=2\end{array}$ & $\begin{array}{c}97 \\
n=3\end{array}$ & $\begin{array}{c}96 \\
n=2\end{array}$ & $\begin{array}{c}98 \\
n=3\end{array}$ & $\begin{array}{c}92 \\
n=3\end{array}$ & $\begin{array}{c}93 \\
n=3\end{array}$ & $\begin{array}{c}82 \\
n=3\end{array}$ & $\begin{array}{c}79 \\
n=3\end{array}$ \\
\hline Age class 6 & $\begin{array}{c}100 \\
n=16\end{array}$ & $\begin{array}{c}100 \\
n=17\end{array}$ & $\begin{array}{c}100 \\
n=16\end{array}$ & $\begin{array}{c}100 \\
n=17\end{array}$ & $\begin{array}{c}100 \\
n=12\end{array}$ & $\begin{array}{c}100 \\
n=20\end{array}$ & $\begin{array}{c}100 \\
n=12\end{array}$ & $\begin{array}{c}100 \\
n=21\end{array}$ \\
\hline
\end{tabular}

(b)

\begin{tabular}{|c|c|c|c|c|}
\hline & \multicolumn{2}{|c|}{ Tail } & \multicolumn{2}{|c|}{ Foot } \\
\hline & Langur & Vervet & Langur & Vervet \\
\hline Age class 1 & $\begin{array}{c}44 \\
n=2\end{array}$ & $\begin{array}{c}45 \\
n=2\end{array}$ & $\begin{array}{c}51 \\
n=2\end{array}$ & $\begin{array}{c}50 \\
n=2\end{array}$ \\
\hline Age class 2 & $\begin{array}{c}51 \\
n=1\end{array}$ & $\begin{array}{c}64 \\
n=2\end{array}$ & $\begin{array}{c}53 \\
n=1\end{array}$ & $\begin{array}{c}66 \\
n=2\end{array}$ \\
\hline Age class 3 & $\begin{array}{c}69 \\
n=4\end{array}$ & $\begin{array}{c}71 \\
n=2\end{array}$ & $\begin{array}{c}77 \\
n=4\end{array}$ & $\begin{array}{c}83 \\
n=2\end{array}$ \\
\hline Age class 4 & $\begin{array}{c}79 \\
n=2\end{array}$ & $\begin{array}{c}93 \\
n=3\end{array}$ & $\begin{array}{c}84 \\
n=2\end{array}$ & $\begin{array}{c}89 \\
n=4\end{array}$ \\
\hline Age class 5 & $\begin{array}{c}96 \\
n=3\end{array}$ & $\begin{array}{c}99 \\
n=3\end{array}$ & $\begin{array}{c}96 \\
n=3\end{array}$ & $\begin{array}{c}99 \\
n=3\end{array}$ \\
\hline Age class 6 & $\begin{array}{c}100 \\
n=12\end{array}$ & $\begin{array}{c}100 \\
n=15\end{array}$ & $\begin{array}{c}100 \\
n=12\end{array}$ & $\begin{array}{c}100 \\
n=18\end{array}$ \\
\hline
\end{tabular}


In a study that included diaphyseal and maximum length measurements in crested langurs, diaphyseal lengths in class 5 are in the adult range whereas the maximum lengths are not [61]. However, this hypothesis is difficult to test without longitudinal data on live animals, which currently do not exist. Another more probable explanation is that the differences are a byproduct of sampling bias.

Several possibilities may explain the variability in langur and vervet growth, and here I focus on two. (1) Molars emerge faster in colobines (langurs), which makes postcranial growth appear immature compared to vervets. In this scenario, only molar teeth grow more rapidly in langurs, but other body systems would not. However, this dental fast-growth explanation is not supported. Some langur somatic elements mature at the same pace as vervets (forelimbs), some later (hip, ankle, tail), and a few earlier (knee elements).

(2) When postcranial growth is compared by molar eruption (regardless of chronological age in years), the mosaic maturity between two species reflects their separate evolutionary histories and/or adaptations. Several explanations may account for these differences: phylogenetic distance, social organization, diet, feeding ecology, geographic location, and locomotion. Here I propose the hypothesis that locomotor differences in crested langurs and vervets may account for the growth differences.

\subsection{Differential Growth Rates: A Function of Locomotion.} Mammals range from very immature and helpless at birth (altricial) to self-sufficient as neonates (precocial). Using brain and muscular development, Grand [76] separates this developmental continuum into four categories. Altricial neonates have small brains and weak muscles, like the giant panda, $98 \%$ of whose growth is postnatal, and who remains nest-bound for the first 3 months of life. In contrast, precocial newborns have large brains and strong muscles, like the wildebeest which moves as an adult ( $30 \mathrm{mph})$ a few hours after birth. Primates are intermediate: large brains (about $50 \%$ of adult size), receptive and responsive to social complexity in early life, but abjectly helpless with weak muscles [76]. They must cling onto the body hair of an adult for transport, a positional behavior reflected in the heavy hands and feet of infants, and well-muscled forearms [77].

Wild primates, for example, baboons, vervets, macaques, and chimps, compared to their captive counterparts have extended growth periods (baboons: e.g., [2, 41], vervets: [55, 78], macaques: [7], chimpanzees: [26, 42-44, 79, 80]). One explanation for this difference between wild and captive growth is that as individuals grow in wild populations, they have greater energy output in their daily lives $[9,44]$. As Altmann so clearly stated based on long-term field studies of baboons, "locomotion probably is the largest energyconsuming activity... for most mammals" [11, page 349]. A recent study on three-toed sloths (Bradypus variegatus) documents that wild animals expend more energy foraging and avoiding predators and sleep less than their captive counterparts [81].
As juveniles make the transition to moving and foraging on their own, their locomotor repertoire expands. As muscular and other body tissues develop and as energy demands increase, one would expect that as feeding ecology and positional behavior vary between species, so would their somatic development. Specifically in vervets the "fastermaturing" postcranial elements (the hip and ankle joint, hindfoot and tail) accelerate their locomotor independence compared to crested langurs. The hindlimb and tail are critical to terrestrial locomotion and may signal the ability to transition between arboreal and terrestrial movement. The hindlimb is dominant in terrestrial walking and bears considerable weight [82]. During locomotion, the long tail of the vervet is critical in propulsive running, leaping, climbing, and balance [83].

Vervets spend about equal amounts of time on the ground and in the trees to forage. This is the justification for their behavior to be described as "semiterrestrial" [84]. In searching for widely distributed resources like fruit, seeds, bark, insects, leaves, grass, and flowers, they must move 600800 meters, which constitutes about $30 \%$ of their day [84].

In contrast, wild crested langurs spend less than $15 \%$ of their day moving, almost exclusively in the trees [49, 85]. These arboreal quadrupeds exhibit less travel then vervets, at 200-500 meters per day [85]. In one species of colobines, the Phayre's leaf monkeys (T. phayrei), the juveniles rely mostly on the accessible leaves, in contrast to preferred, unripe fruits of the adults [66]. This reliance on abundant but less preferred, substantive leaves translates into increased foraging time for juveniles, but not necessarily longer travel times. Langur juveniles therefore may not experience the same locomotor selective pressures on their postcranial development, as do the vervets.

4.4. Link between Locomotion and Skeletal Maturity. Is there a link between locomotion and postcranial maturity? Dynamic compressive forces accelerate long bone epiphyseal fusion in rats [86]. Support for a functional relationship with the regions of maturation in primates is seen with skeletal elements of each joint region fusing around the same time [73, 87]. Typically the sequence of joint fusion (e.g., hip before knee) is conservative among primates, even given locomotor differences [75, 88, 89]. However, there are exceptions. In chimpanzees and orangutans where upper limbs bear weight during suspensory locomotion, the humeral head is accelerated in fusion sequence before the wrist, whereas in most other primates the shoulder fuses after the wrist epiphysis $[73,75]$. In bipedal humans, the ankle and metatarsals of the foot are accelerated in fusion sequence compared with quadrupedal monkeys [73].

The timing of fusion may also reflect locomotor specializations $[61,89]$. In large-bodied leapers like proboscis monkeys (Nasalis larvatus) and red-tailed monkeys (Cercopithecus ascanius), the ilium-to-ischium bones completely fuse before the other two bones of the acetabulum begin to unite; in quadrupedal monkeys, like vervets and mangabeys (Lophocebus albigena), fusion is more uniform across the hip (tri-radiate complex) [61]. 
This relationship between locomotion and postcranial maturity is supported by data from provisioned, free-ranging rhesus macaques (Macaca mulatta) on Cayo Santiago [87]. (Note that methods among this study and the Cayo Santiago study vary slightly). The Cayo Santiago rhesus monkeys over 18 months old are primarily terrestrial (64\%) and quadrupedal $(71 \%)$ with terrestrial/arboreal transitions through leaping $(\sim 10 \%)$ and climbing $(\sim 11 \%)$ [90]. The juvenile rhesus monkeys' hip and ankle region fuse similarly to the vervet sample in this study, both of which are accelerated by age class compared to the arboreal crested langurs.

One study on New World monkey saddle-back tamarins (Saguinus fuscicollis) shows a possible skeletal maturation pattern consistent with vervets, rather than langurs, although the methods differ from this study [91]. In the elbow joint, tamarins are comparable to both langurs and vervets, fusing during class 3 . In the acetabulum/hip joint, tamarins fuse these elements during class 3 , similar to vervets, whereas in langurs the fusion occurs later during class 4 . The knee region appears consistent with vervets in fusing earlier than the langurs, before the time of proximal humerus fusion, or before class 6. Tamarins range daily about 1140-1590 meters which constitutes $20 \%$ of their daily activities $[92,93]$. Another $33 \%$ of the day is spent on foraging for plant matter and insects, in the trees and on the ground [94]. Yearlings carry infant siblings which likely compounds the selective pressures on their locomotor efficiency [95].

Earlier fusion times in vervets, therefore, may be a complex dynamic of selection for immature individuals with more efficient locomotion coupled with the functional demands of mechanical loads that accelerate fusion of particular joints (cf. [96]). Young vervets must move around to get enough food to survive while the crested langur immatures have far less selective pressure for agile locomotion. This study highlights the need for future longitudinal research focusing on the relationship between growth, development, and locomotion in primates.

\section{Conclusions}

This study on dental and skeletal growth of vervet (cercopithecine) and langurs (colobine) monkeys under natural conditions provides a first step in proposing connections between body growth patterns and locomotion. By focusing on postcranial (e.g., long bone, tail, and body mass) as well as cranial (dentition) features, it is possible to connect maturity to behaviors that are essential for survival, especially foraging, traveling, and locomotion and therefore provide a more holistic and integrated view of growth and development. Phylogeny, diet and ecology, as well as locomotion may also influence timing and patterns of growth within a species and more information on growth and development in wild monkeys as well as longitudinal growth data on captive animals will help interpret the contribution of each variable. This approach may also be useful in interpretations of immature fossils, especially in the case of bipedal locomotion and early hominin ancestors.

\section{Acknowledgments}

The author thanks Curatorial Associates Judith Chupasko and Mark Omura at the Museum of Comparative Zoology, Harvard University. He also appreciates the Schultz field note data from Natalie Chaoui and Karin Isler at the Institute and Museum of Anthropology, University of Zurich, Switzerland and thanks Ted Grand, Roberta Lenkeit and Adrienne Zihlman for comments on drafts of this paper, Tessa Toscano for assistance, and the Graduate Division and the Department of Anthropology at the University of California, Santa Cruz for funding.

\section{References}

[1] J. Altmann, S. A. Altmann, G. Hausfater, and S. A. McCuskey, "Life history of yellow baboons: physical development, reproductive parameters, and infant mortality," Primates, vol. 18, no. 2, pp. 315-330, 1977.

[2] J. Altmann, S. Altmann, and G. Hausfater, "Physical maturation and age estimates of yellow baboons, Papio cynocephalus, in Amboseli National Park, Kenya," American Journal of Primatology, vol. 1, pp. 389-399, 1981.

[3] H. Sigg, A. Stolba, J. J. Abegglen, and V. Dasser, "Life history of hamadryas baboons: physical development, infant mortality, reproductive parameters and family relationships," Primates, vol. 23, no. 4, pp. 473-487, 1982.

[4] M. Pereira and J. Altmann, Development of Social Behavior of Free-Living Nonhuman Primates. Nonhuman Primate Models for Human Growth and Development, Alan R Liss, Inc., 1985.

[5] C. J. deRousseau, "Life-history thinking in perspective," in Primate Life History and Evolution, C. J. deRousseau, Ed., pp. 1-13, Wiley-Liss, New York, NY, USA, 1990.

[6] E. Watts, "Evolutionary trends in primate growth and development," in Primate Life History and Evolution, C. J. deRousseau, Ed., pp. 89-104, Wiley-Liss, New York, NY, USA, 1990.

[7] J. Cheverud, P. Wilson, and W. Dittus, "Primate population studies at Plonnaruwa. III. Somatometric growth in a natural population of toque macaques (Macaca sinica)," Journal of Human Evolution, vol. 23, no. 1, pp. 51-77, 1992.

[8] S. R. Leigh, "Patterns of variation in the ontogeny of primate body size dimorphism," Journal of Human Evolution, vol. 23, no. 1, pp. 27-50, 1992.

[9] J. Altmann, D. Schoeller, S. Altmann, P. Muruthi, and R. Sapolsky, "Body size and fatness of free-living baboons reflect food availability and activity levels," American Journal of Primatology, vol. 30, no. 2, pp. 149-161, 1993.

[10] T. R. Turner, F. Anapol, and C. J. Jolly, "Growth, development, and sexual dimorphism in vervet monkeys (Cercopithecus aethiops) at four sites in Kenya," American Journal of Physical Anthropology, vol. 103, no. 1, pp. 19-35, 1997.

[11] S. Altmann, Foraging for Survival: Yearling Baboons in Africa, University of Chicago Press, Chicago, Ill, USA, 1998.

[12] L. R. Godfrey, K. E. Samonds, W. L. Jungers, and M. R. Sutherland, "Teeth, brains, and primate life histories," American Journal of Physical Anthropology, vol. 114, no. 3, pp. 192-214, 2001.

[13] W. Dirks, "Effect of diet on dental development in four species of catarrhine primates," American Journal of Primatology, vol. 61, no. 1, pp. 29-40, 2003. 
[14] G. T. Schwartz, D. J. Reid, M. C. Dean, and A. L. Zihlman, “A faithful record of stressful life events preserved in the dental developmental record of a juvenile gorilla," International Journal of Primatology, vol. 27, no. 4, pp. 1201-1219, 2006.

[15] W. Dirks and J. E. Bowman, "Life history theory and dental development in four species of catarrhine primates," Journal of Human Evolution, vol. 53, no. 3, pp. 309-320, 2007.

[16] D. R. Bolter and A. L. Zihlman, "Primate growth and development: a functional and evolutionary approach," in Primates in Perspective, C. Campbell, A. Fuentes, K. MacKinnon, S. Bearder, and R. Stumpf, Eds., pp. 428-439, Oxford University Press, New York, NY, USA, 2nd edition, 2011.

[17] G. T. Schwartz, K. E. Samonds, L. R. Godfrey, W. L. Jungers, and E. L. Simons, "Dental microstructure and life history in subfossil Malagasy lemurs," Proceedings of the National Academy of Sciences of the United States of America, vol. 99, no. 9, pp. 6124-6129, 2002.

[18] G. T. Schwartz, P. Mahoney, L. R. Godfrey, F. P. Cuozzo, W. L. Jungers, and G. F. N. Randria, "Dental development in Megaladapis edwardsi (Primates, Lemuriformes): implications for understanding life history variation in subfossil lemurs," Journal of Human Evolution, vol. 49, no. 6, pp. 702-721, 2005.

[19] M. C. Nargolwalla, D. R. Begun, M. C. Dean, D. J. Reid, and L. Kordos, "Dental development and life history in Anapithecus hernyaki," Journal of Human Evolution, vol. 49, no. 1, pp. 99121, 2005.

[20] K. Harvati and S. R. Frost, "Dental eruption sequences in fossil colobines and the evolution of primate life histories," International Journal of Primatology, vol. 28, no. 3, pp. 705$728,2007$.

[21] J. Kelley and G. T. Schwartz, "Dental development and life history in living African and Asian apes," Proceedings of the National Academy of Sciences of the United States of America, vol. 107, no. 3, pp. 1035-1040, 2010.

[22] S. Gould, Ontogeny and Phylogeny, Belknap Press, Cambridge, UK, 1977.

[23] B. Shea, "Current issues in the investigation of evolution by heterochrony, with emphasis on the debate over human neoteny," in Biology, Brains, and Behavior: The Evolution of Human Development, S. Parker, J. Langer, and M. McKinney, Eds., pp. 181-213, SAR Press, Santa Fe, NM, USA, 2000.

[24] K. K. Smith, "Sequence heterochrony and the evolution of development," Journal of Morphology, vol. 252, no. 1, pp. 8297, 2002.

[25] S. J. King, "Relative timing of ontogenetic events in primates," Journal of Zoology, vol. 264, no. 3, pp. 267-280, 2004.

[26] A. Pusey, The physical and social development of wild adolescent chimpanzees (Pan trolgodytes schweinfurthii), dissertation, Stanford University, Palo Alto, Calif, USA, 1978.

[27] A. Gautier-Hion, F. Bourliere, J. Gautier, and J. Kingdon, Eds., A Primate Radiation: Evolutionary Biology of the African Guenons, Cambridge University Press, Cambridge, UK, 1988.

[28] D. Cheney and R. Seyfarth, How Monkeys See the World: Inside the Mind of Another Species, University of Chicago Press, Chicago, Ill, USA, 1990.

[29] D. Cheney and R. Seyfarth, Baboon Metaphysics, University of Chicago Press, Chicago, Ill, USA, 2007.

[30] M. Cords and M. Glenn, Eds., The Guenons: Diversity and Adaptation in African Monkeys, Plenum, New York, NY, USA, 2002.

[31] A. G. Davies and J. F. Oates, Eds., Colobine Monkeys: Their Ecology, Behaviour and Evolution, Cambridge University Press, Cambridge, UK, 1994.
[32] B. H. Smith, "Dental development as a measure of life history in primates," Evolution, vol. 43, no. 3, pp. 683-688, 1989.

[33] T. Ockerse, "The anatomy of the teeth of the vervet monkey," Journal of the Dental Association of South Africa, vol. 14, pp. 209-226, 1959.

[34] E. Kerley, "Skeletal age changes in the chimpanzee," Tulane Studies in Zoology and Botany, vol. 13, pp. 71-82, 1966.

[35] C. A. Bramblett, L. D. Pejaver, and D. J. Drickman, "Reproduction in captive vervet and Sykes' monkeys," Journal of Mammalogy, vol. 56, no. 4, pp. 940-946, 1975.

[36] A. Mori, "Analysis of population changes by measurement of body weight in the Koshima troop of Japanese monkeys," Primates, vol. 20, no. 3, pp. 371-397, 1979.

[37] Y. Hamada, M. Iwamoto, and T. Watanabe, "Somatometrical features of Japanese monkeys in the Koshima islet: in viewpoint of somatometry, growth, and sexual maturation," Primates, vol. 27, no. 4, pp. 471-484, 1986.

[38] G. C. Conroy and C. J. Mahoney, "Mixed longitudinal study of dental emergence in the chimpanzee, Pan troglodytes (Primates, Pongidae)," American Journal of Physical Anthropology, vol. 86, no. 2, pp. 243-254, 1991.

[39] S. R. Leigh, "Ontogenetic correlates of diet in anthropoid primates," American Journal of Physical Anthropology, vol. 94, no. 4, pp. 499-522, 1994.

[40] L. Fairbanks, "Maternal investment throughout the life span in Old World monkeys," in Old World Monkeys, P. Whitehead and C. Jolly, Eds., pp. 341-367, Cambridge University Press, Cambridge, UK, 2000.

[41] J. E. Phillips-Conroy and C. J. Jolly, "Dental eruption schedules of wild and captive baboons," American Journal of Primatology, vol. 15, no. 1, pp. 17-29, 1988.

[42] T. Kimura and Y. Hamada, "Development of epiphyseal union in Japanese macaques of known chronological age," Primates, vol. 31, no. 1, pp. 79-93, 1990.

[43] A. L. Zihlman, D. R. Bolter, and C. Boesch, "Wild chimpanzee dentition and its implications for assessing life history in immature hominin fossils," Proceedings of the National Academy of Sciences of the United States of America, vol. 101, no. 29, pp. 10541-10543, 2004.

[44] A. L. Zihlman, D. R. Bolter, and C. Boesch, "Skeletal and dental growth and development in chimpanzees of the Taï National Park, Côte D’Ivoire," Journal of Zoology, vol. 273, no. 1, pp. 63-73, 2007.

[45] C. Janson and C. van Schaik, "Ecological risk aversion in juvenile primates: slow and steady wins the race," in Juvenile Primates, M. Pereira and L. Fairbanks, Eds., pp. 57-74, Oxford University Press, New York, NY, USA, 1993.

[46] A. Schultz, "Growth and development of the proboscis monkey," Bulletin of the Museum of Comparative Zoology, vol. 89, pp. 279-323, 1942.

[47] J. Gartlan and C. Brain, "Ecology and social variability in Cercopithecus aethiops and C. mitis," in Primates: Studies in Adaptation and Variability, P. Jay, Ed., pp. 253-292, Holt, Rinehart and Winston, New York, NY, USA, 1968.

[48] P. Whitten, Female reproductive strategies among vervet monkeys, dissertation, Harvard University, Cambridge, Mass, USA, 1982.

[49] K. E. Wolf, Reproductive competition among co-resident male silvered leaf monkeys (Presbytis cristatus), dissertation, Yale University, New Haven, Conn, USA, 1984.

[50] P. Harvey and T. Clutton-Brock, "Life history variation in primates," Evolution, vol. 39, pp. 559-581, 1985. 
[51] J. A. Horrocks, "Life-history characteristics of a wild population of vervets (Cercopithecus aethiops sabaeus) in Barbados, West Indies," International Journal of Primatology, vol. 7, no. 1, pp. 31-47, 1986.

[52] L. A. Fairbanks and M. T. McGuire, "Age, reproductive value, and dominance-related behaviour in vervet monkey females: cross-generational influences on social relationships and reproduction," Animal Behaviour, vol. 34, no. 6, pp. 17101721, 1986.

[53] P. Harvey, R. Martin, and T. Clutton-Brock, "Life histories in comparative perspective," in Primate Societies, B. Smuts, D. Cheney, R. Seyfarth, R. Wrangham, and T. Struhsaker, Eds., pp. 181-196, Chicago University Press, Chicago, Ill, USA, 1987.

[54] T. Butynski, "Guenon birth seasons and correlates with rainfall and food," in A Primate Radiation: Evolutionary Biology of the African Guenons, A. Gautier-Hion, F. Bourliere, J.-P. Gautier, and J. Kingdon, Eds., pp. 284-322, Cambridge University Press, Cambridge, UK, 1988.

[55] D. Cheney, R. Seyfarth, S. Andelman, and P. Lee, "Reproductive success in vervet monkeys," in Reproductive Success: Studies of Individual Variation in Contrasting Breeding Systems, T. Clutton-Brock, Ed., pp. 384-402, Chicago University Press, Chicago, Ill, USA, 1988.

[56] J. Horrocks and W. Hunte, "Interactions between juveniles and adult males in vervets: implications for adult male turnover," in Juvenile Primates: Life History, Development, and Behavior, M. Pereira and L. Fairbanks, Eds., pp. 228-239, Oxford University Press, New York, NY, USA, 1993.

[57] E. Bennett and A. Davies, "The ecology of Asian colobines," in Colobine Monkeys, A. G. Davies and J. F. Oates, Eds., pp. 129172, Cambridge University Press, Cambridge, UK, 1994.

[58] C. Yeager and K. Kool, "The behavioral ecology of Asian colobines," in Old World Monkeys, C. Jolly and P. Whitehead, Eds., pp. 496-521, Cambridge University, Cambridge, UK, 2000.

[59] P. Kappeler and M. Pereira, Primate Life Histories and Socioecology, University of Chicago Press, Chicago, Ill, USA, 2003.

[60] D. R. Bolter and A. L. Zihlman, "Morphometric analysis of growth and development in wild-collected vervet monkeys (Cercopithecus aethiops), with implications for growth patterns in Old World monkeys, apes and humans," Journal of Zoology, vol. 260, no. 1, pp. 99-110, 2003.

[61] D. R. Bolter, Anatomical Growth Patterns in Colobine Monkeys and Implications for Primate Evolution (Trachypithecus cristatus, Presbytis rubicunda, Nasalis larvatus), University of California, Santa Cruz, Calif, USA, 2004.

[62] G. Allen and H. Coolidge, "Mammal and bird collections of the Asiatic primate expedition: mammals," Bulletin of the Museum of Comparative Zoology, vol. 87, pp. 131-166, 1940.

[63] A. Schultz, "The technique of measuring the outer body of human fetuses and of primates in general," Contributions to Embryology, vol. 117, pp. 213-257, 1929.

[64] M. Q. Nian, "The growth of Presbytis francoisi," in Proceedings of International Seminar on Commemorating the Naming of Francois' Leaf Monkey for Its First Centenary and Protection of the Primate, Wuzhou, China, 1998.

[65] T. Nadler, F. Momberg, N. X. Dang, and N. Lormée, Vietnam Primate Conservation Status Review 2002. Part 2: Leaf Monkeys-Fauna and Flora, International-Vietnam Program and Frankfurt Zoological Society, Hanoi, Vietnam, 2003.
[66] K. Ossi, C. Borries, and A. Koenig, "First evidence for ecological risk among juvenile Phayre's leaf monkeys," American Journal of Physical Anthropology, vol. 42, p. 142, 2006.

[67] A. Schultz, "Growth and development of the chimpanzee," Contributions to Embryology, vol. 170, pp. 3-63, 1940.

[68] A. Schultz, "Eruption and decay of the permanent teeth in primates," American Journal of Physical Anthropology, vol. 19, pp. 489-581, 1935.

[69] A. Schultz, "Postembryonic age changes," Primatologia, vol. 1, pp. 887-965, 1956.

[70] B. H. Smith, T. L. Crummett, and K. L. Brandt, "Ages of eruption of primate teeth: a compendium for aging individuals and comparing life histories," American Journal of Physical Anthropology, vol. 95, no. 19, pp. 177-231, 1994.

[71] J. Kelley and T. M. Smith, "Age at first molar emergence in early Miocene Afropithecus turkanensis and life-history evolution in the Hominoidea," Journal of Human Evolution, vol. 44, no. 3, pp. 307-329, 2003.

[72] J. G. Wintheiser, D. A. Clauser, and N. C. Tappen, "Sequence of eruption of permanent teeth and epiphyseal union in three species of African monkeys," Folia Primatologica, vol. 27, no. 3, pp. 178-197, 1977.

[73] S. L. Washburn, "The sequence of epiphyseal union in Old World monkeys," American Journal of Anatomy, vol. 72, no. 3, pp. 339-360, 1943.

[74] A. Schultz, Life of Primates, Weidenfeld and Nicolson, London, UK, 1969.

[75] N. Shigehara, "Epiphyseal union, tooth eruption, and sexual maturation in the common tree shrew, with reference to its systematic problem," Primates, vol. 21, no. 1, pp. 1-19, 1980.

[76] T. I. Grand, "Altricial and precocial mammals: a model of neural and muscular development," Zoo Biology, vol. 11, pp. 3-15, 1992.

[77] T. I. Grand, "Body weight: its relation to tissue composition, segment distribution, and motor function. II. Development of Macaca mulatta," American Journal of Physical Anthropology, vol. 47, no. 2, pp. 241-248, 1977.

[78] C. A. Bramblett, "A model for development of social behavior in vervet monkeys," Developmental Psychobiology, vol. 13, no. 2, pp. 205-223, 1980.

[79] E. Watts, "Epiphyseal union in captive chimpanzees," American Journal of Physical Anthropology, vol. 16, p. 206, 1993.

[80] C. Boesch and H. Boesch-Achermann, The Chimpanzees of the Taï Forest: Behavioural Ecology and Evolution, Oxford University Press, Oxford, UK, 2000.

[81] N. C. Rattenborg, B. Voirin, A. L. Vyssotski et al., "Sleeping outside the box: electroencephalographic measures of sleep in sloths inhabiting a rainforest," Biology Letters, vol. 4, no. 4, pp. 402-405, 2008.

[82] T. I. Grand, "The functional anatomy of body mass," in Body Size in Mammalian Paleobiology: Estimation and Biological Implications, J. Damuth and B. MacFadden, Eds., pp. 39-47, Cambridge University Press, Cambridge, UK, 1990.

[83] F. Anapol, T. R. Turner, C. S. Mott, and C. J. Jolly, "Comparative postcranial body shape and locomotion in Chlorocebus aethiops and Cercopithecus mitis," American Journal of Physical Anthropology, vol. 127, no. 2, pp. 231-239, 2005.

[84] R. I. Dunbar and E. P. Dunbar, "Ecological relations and niche separation between sympatric terrestrial primates in Ethiopia," Folia Primatologica, vol. 21, no. 1, pp. 36-60, 1974.

[85] I. S. Bernstein, “The Lutong of Kuala Selangor," Behaviour, vol. 32, pp. 1-16, 1968. 
[86] M. R. Simon, "The effect of dynamic loading on the growth of epiphyseal cartilage in the rat," Acta Anatomica, vol. 102, no. 2, pp. 176-183, 1978.

[87] J. M. Cheverud, "Epiphyseal union and dental eruption in Macaca mulatta," American Journal of Physical Anthropology, vol. 56, no. 2, pp. 157-167, 1981.

[88] A. Schultz, "The comparative uniformity of the Cercopithecoid," in Old World Monkeys: Evolution, Systematics, and Behavior, J. Napier and P. Napier, Eds., pp. 39-51, Academic Press, New York, NY, USA, 1970.

[89] S. J. King, L. R. Godfrey, and E. L. Simons, "Adaptive and phylogenetic significance of ontogenetic sequences in archaeolemur, subfossil lemur from medagascar," Journal of Human Evolution, vol. 41, no. 6, pp. 545-576, 2001.

[90] J. P. Wells and J. E. Turnquist, "Ontogeny of locomotion in rhesus macaques (Macaca mulatta): II. Postural and locomotor behavior and habitat use in a free-ranging colony," American Journal of Physical Anthropology, vol. 115, no. 1, pp. 80-94, 2001.

[91] D. M. Glassman, "Growth and development in the saddleback tamarin: the sequence and timing of dental eruption and epiphyseal union," American Journal of Primatology, vol. 5, no. 1, pp. 51-60, 1983.

[92] J. Terborgh, Five New World Primates: A Study in Comparative Ecology, Princeton University Press, Princeton, NJ, USA, 1983.

[93] A. W. Goldizen, "Tamarin and marmoset mating systems: unusual flexibility," Trends in Ecology and Evolution, vol. 3, no. 2, pp. 36-40, 1988.

[94] L. Digby, S. Ferrari, and W. Saltzman, "Callitrichines: the role of competition in cooperatively breeding species," in Primates in Perspective, C. Campbell, A. Fuentes, K. MacKinnon, M. Panger, and S. Bearder, Eds., pp. 85-106, Oxford University Press, New York, NY, USA, 2007.

[95] J. Terborgh and A. W. Goldizen, "On the mating system of the cooperatively breeding saddle-backed tamarin (Saguinus fuscicollis)," Behavioral Ecology and Sociobiology, vol. 16, no. 4, pp. 293-299, 1985.

[96] D. R. Carter and G. S. Beaupré, Skeletal Function and Form, Cambridge University Press, London, UK, 2001. 

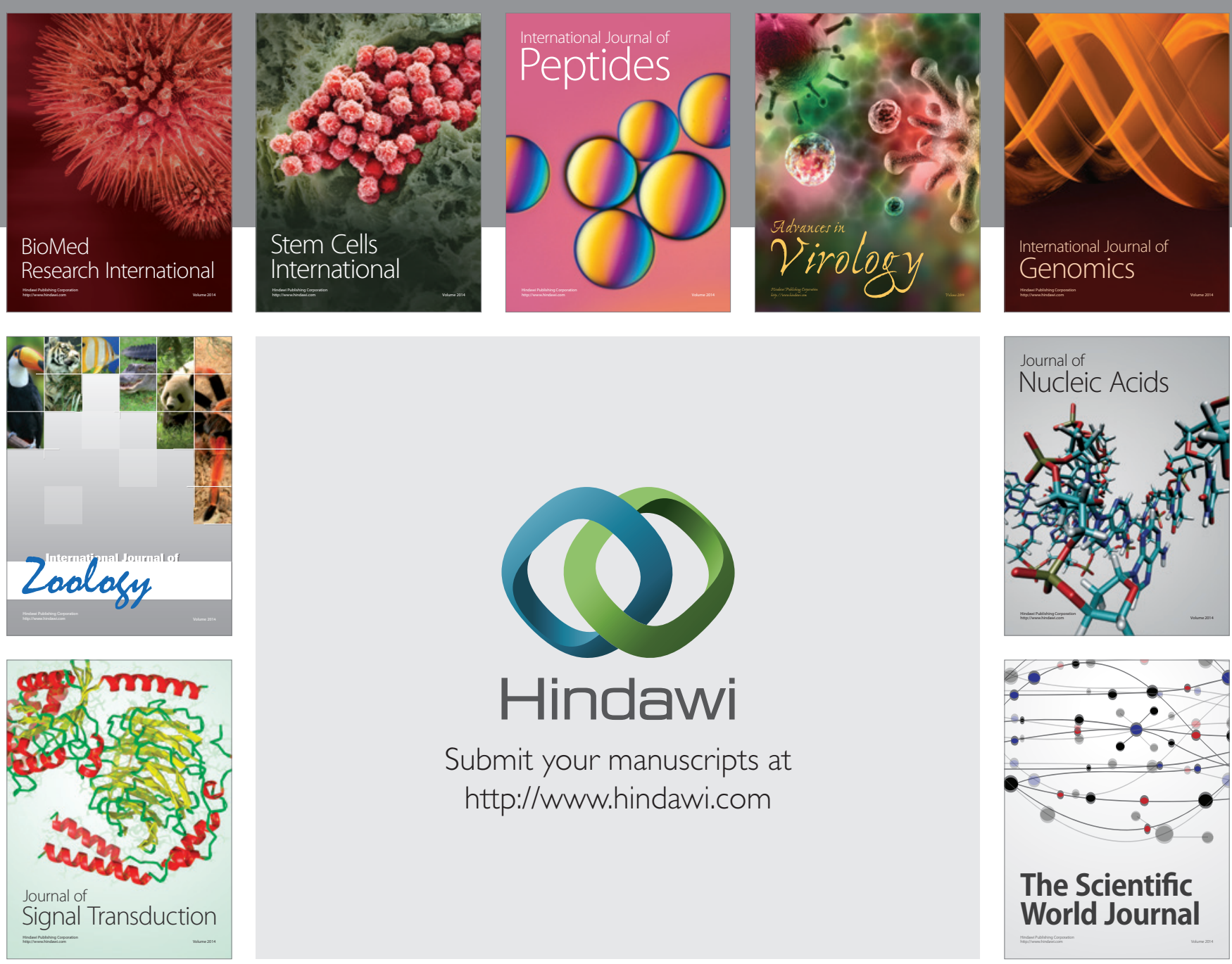

Submit your manuscripts at

http://www.hindawi.com
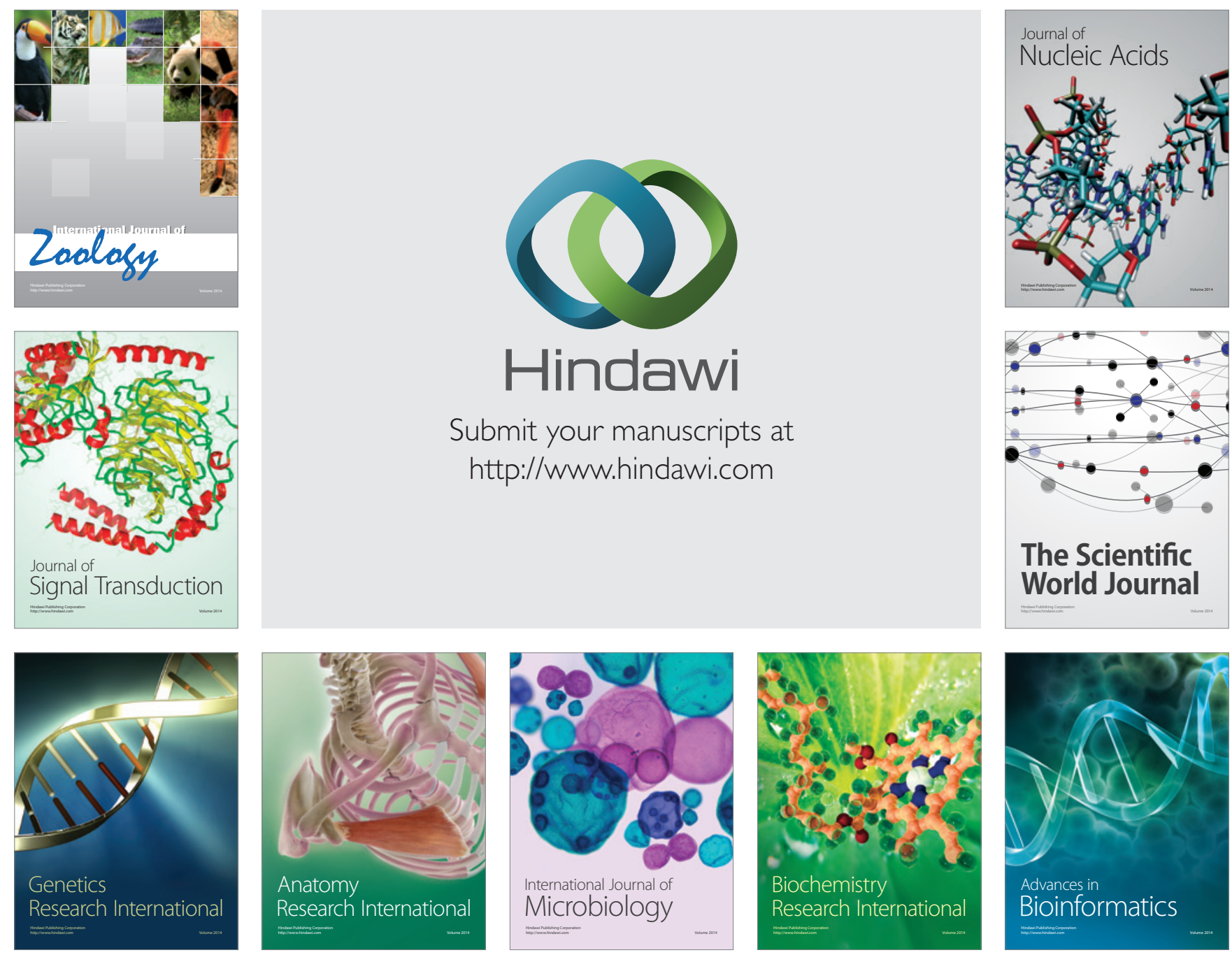

The Scientific World Journal
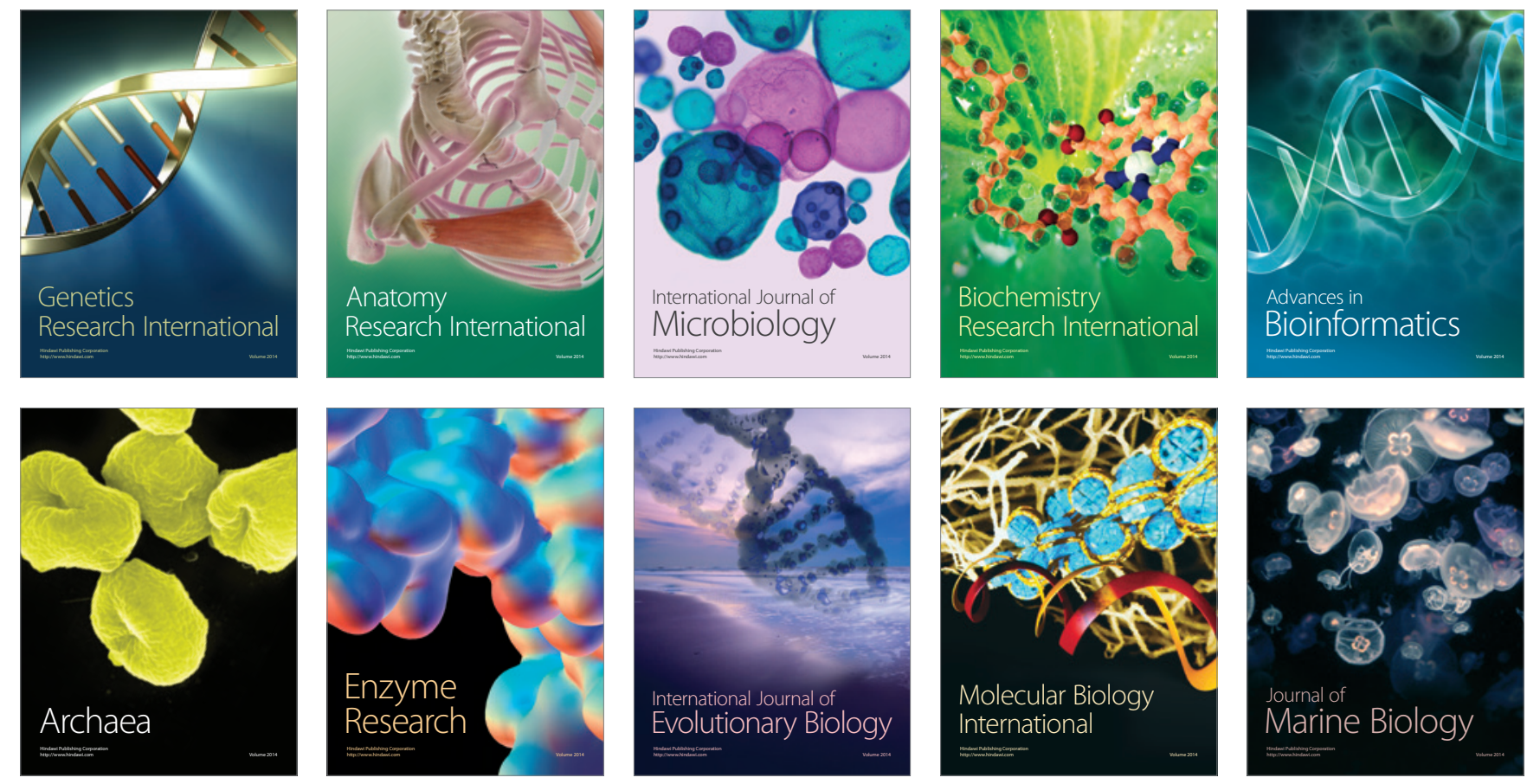